\title{
EFEKTIVITAS KARBON AKTIF JERAMI SEBAGAI ADSORBEN UNTUK MENURUNKAN KADAR MANGAN (Mn) AIR SUMUR GALI \\ (Studi di Puskesmas Krian pada Ruang UGD Kabupaten Sidoarjo 2019)
}

Sari Putri Utami, Demes Nurmayanti, Marlik

Jurusan Kesehatan Lingkungan Poltekkes Kemenkes Surabaya

Email : saripu2407@gmail.com

\begin{abstract}
ABSTRAK
Untuk memenuhi persyaratan kesehatan, diperlukan pemrosesan air bersih yang berkualitas. Sebagian air sumur mengandung mineral tinggi dalam bentuk mangan, kandungan mangan lebih dari 0,5 mg / L dapat mengganggu kesehatan manusia, maka perlu proses proses adsorpsi. Jerami sebagai adsorben mengandung selulosa yang dapat mengikat ion logam. Penelitian ini bertujuan untuk menentukan efektivitas karbon aktif jerami sebagai bahan adsorben dalam mengurangi kandungan mangan dalam air sumur gali.

Jenis penelitian ini adalah eksperimen dengan desain one group pretest-posttest. Penelitian dilakukan dalam 7 perlakuan dengan kontrol, dan variasi dalam massa jerami karbon aktif adalah 5 gr, 10 gr, 15 gr, 20 gr, 25 gr, 30 gr. Analisis data menggunakan uji One Way Anova.

Hasil penelitian menunjukkan bahwa adsorpsi karbon aktif jerami dapat mengurangi kadar mangan dalam air sumur secara berturut-turut untuk massa jerami 0 gr, $5 \mathrm{gr}, 10 \mathrm{gr}, 15 \mathrm{gr}, 20 \mathrm{gr}, 25 \mathrm{gr}$ dan $30 \mathrm{gr}$ adalah $1,119 \mathrm{mg} / \mathrm{L}$ menjadi $1,161 \mathrm{mg} / \mathrm{L}$, $1,127 \mathrm{mg} / \mathrm{L}, 1,132 \mathrm{mg} / \mathrm{L}, 0,984 \mathrm{mg} / \mathrm{L}, 0,972 \mathrm{mg} / \mathrm{L}, 0,977 \mathrm{mg} / \mathrm{L}$, dan 0,855 mg/L. Berdasarkan hasil uji One Way Anova dan uji tindak lanjut LSD yang diperoleh oleh kelompok perlakuan yang memiliki pengaruh terbesar pada rata-rata dalam menurunkan kadar air mangan di dalam sumur, yaitu massa $30 \mathrm{gr}$ dengan efisiensi dari 23,59\%.

Disimpulkan bahwa adsorpsi karbon aktif jerami mampu menurunkan kadar mangan (Mn) tetapi belum efektif. Massa yang memiliki pengaruh besar rata-rata dalam mengurangi kadar mangan adalah 30 gr. Penelitian lebih lanjut diperlukan untuk dapat mencapai efisiensi adsorpsi dan menemukan upaya untuk mengurangi kekeruhan dalam sampel air setelah pengolahan dan direkomendasikan untuk meningkatkan variasi massa karbon aktif jerami.
\end{abstract}

Kata kunci : sumur gali, mangan, karbon aktif jerami

\section{PENDAHULUAN}

Air tanah merupakan sumberdaya alam yang potensial dalam upaya memenuhi kebutuhan air bersih. Sebagian air tanah mengandung mineral dalam konsentrasi tinggi berupa besi dan mangan. Keberadaan besi dalam air bersamaan dengan mineral mangan, tetapi besi lebih sering didapatkan daripada mangan (Joko, T.2010). Namun demikian jika kandungan mangan pada air tanah melebihi syarat yang ditentukan dalam Permenkes No. 32 tahun 2017 dapat menimbulkan gangguan pada kesehatan manusia.

Permasalahan kualitas air bersih dengan kadar Mn yang tinggi ditemukan di Puskesmas Krian bagian UGD,
Kecamatan Krian, Kabupaten Sidoarjo, hasil survei pendahuluan diperoleh bahwa pemanfaatan sumber air bersih Puskesmas Krian berasal dari air sumur yang digunakan untuk kebutuhan proses kegiatan di UGD. Jika diamati secara fisik kondisi air sumur berwarna kuning yang mengidikasikan adanya kandungan $\mathrm{Mn}$ yang tinggi (Fauziah, A. 2010). Untuk memastikannya dilakukan uji laboratorium dan diperoleh hasil kandungan $\mathrm{Mn}$ sebesar 5,278 mg/l. Kondisi ini tentu tidak memenuhi syarat kualitas air bersih dimana standar baku mutu air bersih untuk kandungan $\mathrm{Mn}$ menurut Peraturan Menteri Kesehatan RI Nomor 32 tahun 2017 adalah maksimum $0.5 \mathrm{mg} / \mathrm{l}$. Oleh karena itu, agar air 
tersebut tetap bisa digunakan sebagai sumber air bersih maka perlu adanya suatu proses pengolahan air terlebih dahulu.

Salah satu metode untuk mengurangi logam berat pada air tercemar dan air limbah yaitu dengan metode adsorpsi (Said, N.I., 2010). Metode adsorpsi dinilai menjadi metode yang sangat sederhana, ekonomis, efektif, dan serbaguna untuk menghilangkan kontaminan beracun dalam air limbah (Lakherwal, D., 2014). Metode adsorpsi dapat dilakukan dengan cara pengontakan pada air dan proses pengadukan. Berdasarkan penelitian yang dilakukan Abdi, Chairul, dkk (2015) penurunan kadar besi dan mangan dapat dilakukan dengan proses adsorpsi karbon aktif. Dalam penelitiannya mangan dan besi dapat diturunkan dengan menggunakan karbon aktif berbahan dasar kulit pisang kapok. Arang kulit pisang kepok memiliki kemampuan adsorben karena mengandung selulosa.

Salah satu material yang dapat dipertimbangkan sebagai adsorben adalah jerami. Jerami dapat dijadikan pertimbangan sebagai adsorben karena mudah diperoleh dan murah maka karbon aktif jerami dapat digunakan sebagai media adsorben untuk menurunkan kadar mangan pada air sumur gali.

Jerami merupakan bagian vegetatif berupa batang, daun, dan tangkai dari tanaman padi. Produksi gabah kering giling (GKG) menurut data Badan Pusat Statistik Provinsi Jawa Timur pada tahun 2017 mencapai 13.060 .464 ton. Wilayah Sidoarjo jumlah GKG sebesar 204.425 ton. Berdasarkan data Litbang Pertanian, untuk 1 ton gabah GKG dari pertanaman padi mampu menghasilkan 1,5 ton jerami. Jumlah produksi GKG di Sidoarjo maka potensi jerami padi yang tersedia yaitu sekitar 306.637,5 ton. Jerami memiliki banyak fungsi, diantaranya sebagai bahan bakar, pakan ternak, alas atau lantai kandang, pengemas bahan pertanian (misal telur), bahan bangunan dan kerajinan tangan. Namun, jumlah jerami padi yang melimpah tersebut belum dimanfaatkan secara optimal oleh petani untuk menambah nilai guna.

\section{METODE PENELITIAN}

Jenis penelitian ini adalah eksperimen, dengan desain penelitian "one grup pretest-posttest design".Sampel dan besar sampel dalam penelitian ini berjumlah 28 liter sampel air, penelitian dilakukan sebanyak 7 perlakuan dengan kontrol, variasi kadar yakni 5 gr, 10 gr, 15 gr, 20 gr, 25 gr, dan 30 gr. Berdasarkan hasil perhitungan diatas didapatkan hasil sebesar 4 replikasi. Teknik pengambilan sampel menggunakan metode grab sampel. Variabel penelitian terdiri dari independen variable yaitu massa karbon aktif jerami dan dependent variable yaitu kadar mangan dalam sampel air tanah dengan variabel kontrol yaitu $\mathrm{pH}$, suhu, waktu kontak dan kecepatan pengadukan. Teknik pengumpulan data melalui metode observasi, wawancara dan pengukuran langsung dari pembuatan adsorben, saat melakukan adsorpsi, kadar mangan pada sampel air sumur gali. Analisis data memakai one way anova dan dilanjutkan denan uji LSD.

\section{HASIL DAN PEMBAHASAN \\ Adsorben Karbon Aktif Jerami}

Pembuatan adsorben dimulai dari pengambilan jerami yang diambil langsung dari sawah yang telah dipanen. Batang padi berbuku dan berongga. Dari buku batang ini tumbuh anakan yaitu daun (Purwono, 2009). Jerami adalah hasil sampingan usaha pertanian berupa tangkai atau batang tanaman padi yang telah kering, setelah bijinya dipisahkan. Pembuatan karbon aktif berlangsung tiga tahap yaitu proses dehidrasi, proses karnonisasi, dan proses aktivasi (Aisyah, 2010). Seberat $3 \mathrm{~kg}$ jerami diambil, dicuci dan dikeringkan dibawah sinar matahari. Proses karbonisasi pada suhu $500^{\circ} \mathrm{C}$ selama 15 menit jerami menjadi arang. Penelitian ini menggunakan aktivasi secara fisik yaitu pembakaran. Pada proses karbonisasi/ aktivasi secara fisik saja sudah bisa di lakukan untuk penurunan air yang mengandung logam. 
Kapasitas adsorpsi dari karbon aktif tergantung pada jenis pori dan jumlah permukaan yang mungkin dapat digunakan untuk mengadsorpsi (Asbahani, 2013).

Massa karbon aktif jerami dalam proses adsorpsi juga dipengaruhi oleh waktu kontak optimum dan kecepatan pengadukan menurut (Asbahani, 2013) waktu kontak yang cukup diperlukan oleh karbon aktif agar dapat mengadsorbsi besi secara optimal. Semakin lama waktu kontak maka semakin banyakpartikel karbon aktif untuk bersinggungan dengan logam besi yang terikat di dalam pori-pori karbon aktif. Disamping massa, waktu kontak, temperatur, dan $\mathrm{pH}$ juga memberikan kontribusi dalam proses adsorpsi. Menurut Syauqiah Isna, dkk (2011) faktor temperatur aktivasi adsorben dengan pemanasan secara fisik juga mempengaruhi proses adsorpsi antara adsorben dan adsorbat. Pemanasan akan menyebabkan pori-pori permukaan adsorben terbuka sehingga meningkatkan daya serap adsorben terhadap adsorbat, pemanasan yang terlalu tinggi menyebabkan rusaknya adsorben sehingga menurunkan kemampuan adsorpsi. Zhaafirah, dkk (2017) juga menyatakan bahwa suhu pada proses adsorpsi juga mempengaruhi jumlah adsorpsi yang terjadi. Kecepatan adsorpsi akan meningkatkan dengan naiknya suhu dan sebaliknya. Namun dalam penelitian ini menggunakan aktivasi secara fisika yaitu menggunakan pembakaran suhu panas sebesar $500^{\circ} \mathrm{C}$ selama 15 menit (Aisyah, 2010) Pembentukan karbon terjadi pada temperatur $400-600^{\circ} \mathrm{C}$, dan proses aktivasi (dekomposisi menghasilkan tar dan perluasan pori-pori. Dapat dilakukan dengan uap atau $\mathrm{CO}_{2}$ sebagai aktivator). Air berpotensi mengurangi proses adsorpsi terhadap ion logam sehingga menurunkan mutu adsorben. Untuk mengurangi kadar air maka dilakukan dengan pemanasan dan karbonisasi menjadi karbon yang kemudian diaktivasi menjadi karbon aktif. Menurut Atmoko (2012) aktivasi karbon aktif bertujuan untuk membuka pori-pori karbon yang tertutupi oleh zat-zat sisa proses karbonisasi sehingga kemampuan daya serapnya menjadi lebih optimal.

\section{Kadar Mangan (Mn) sebelum dan Sesudah Penambahan Adsorben Karbon Aktif Jerami}

Tabel 1

HASIL PENGUKURAN KADAR MANGAN PADA AIR SUMUR GALI SESUDAH PENAMBAHAN KARBON AKTIF JERAMI

\begin{tabular}{|c|c|c|c|c|c|c|}
\hline \multirow{2}{*}{$\begin{array}{l}\text { Kadar } \\
\text { (gr/L) }\end{array}$} & \multicolumn{4}{|c|}{ Kadar Mn (mg/L) pada Replikasi ke } & \multirow{2}{*}{$\begin{array}{c}\text { Jumlah } \\
\text { Kadar mangan } \\
(\mathrm{mg} / \mathrm{L})\end{array}$} & \multirow{2}{*}{$\begin{array}{c}\text { Rata-rata } \\
(\mathrm{mg} / \mathrm{L})\end{array}$} \\
\hline & 1 & 2 & 3 & 4 & & \\
\hline 0 & 1.318 & 1.088 & 1.138 & 1.101 & 4.645 & 1.161 \\
\hline 5 & 0.984 & 1.204 & 1.226 & 1.096 & 4.51 & 1.127 \\
\hline 10 & 1.220 & 1.154 & 1.043 & 1.114 & 4.531 & 1.132 \\
\hline 15 & 0.994 & 0.961 & 0.975 & 1.007 & 3.937 & 0.984 \\
\hline 20 & 0.854 & 1.015 & 0.953 & 1.067 & 3.889 & 0.972 \\
\hline 25 & 1.017 & 1.025 & 0.995 & 0.874 & 3.911 & 0.977 \\
\hline 30 & 0.792 & 0.909 & 0.884 & 0.836 & 3.421 & 0.855 \\
\hline
\end{tabular}

Berdasarkan Tabel 1 diketahui bahwa terjadi penurunan kadar Mn pada sampel air Sumur gali sesudah dilakukannya pengolahan menggunakan metode jartes dengan massa jerami $5 \mathrm{gr}$, $10 \mathrm{gr}, 15 \mathrm{gr}, 20 \mathrm{gr}, 25 \mathrm{gr}$, dan $30 \mathrm{gr}$. Kadar $\mathrm{Mn}$ rata-rata pada kelompok kontrol (0 gr) didapatkan hasil sebesar $1.161 \mathrm{mg} / \mathrm{L}$. Penurunan terbesar kadar
Mn rata-rata terjadi pada proses pengolahan sampel air sumur gali yang menggunakan massa sebesar $30 \mathrm{gr}$ yaitu sebesar $0.855 \mathrm{mg} / \mathrm{L}$. Sedangkan kadar Mn rata-rata hasil perlakuan dengan besar massa jerami 25 gr yaitu sebesar $0.977 \mathrm{mg} / \mathrm{L}, 20 \mathrm{gr}$ yaitu sebesar $0.972 \mathrm{mg} / \mathrm{L}, 15 \mathrm{gr}$ yaitu sebesar 0.984 $\mathrm{mg} / \mathrm{L}, 10 \mathrm{gr}$ yaitu sebesar $1.132 \mathrm{mg} / \mathrm{L}$. 
Sementara itu, penurunan kadar Mn ratarata terkecil terjadi pada massa jerami 5 gr yaitusebesar $1.127 \mathrm{mg} / \mathrm{L}$.

Pemerikasaan hasil kadar mangan (Mn) sebelum dilakukan perlakuan penambahan adsorben karbon aktif jerami atau kode sampel A air sumur gali diperoleh rata-rata sebesar $1.161 \mathrm{mg} / \mathrm{L}$. Berdasarkan hasil yang dperoleh maka diketahui sample air sumur gali belum memenuhi Peraturan Menteri Kesehatan RI No. 32 tahun 2017 tentang standar baku mutu untuk air yang digunakan untuk keperluan higiene sanitasi yaitu 0,5 $\mathrm{mg} / \mathrm{L}$. Mangan yang berasal dari air lebih mudah terserap oleh tubuh daripada yang berasal dari bahan makanan (Bouchard, 2010). Menurut Widowati (2008) sehingga kadar mangan yang tinggi dapat membahayakan tubuh dan mengakibatkan toksisitas pada sistem syaraf pusat. Merugikan bila teroksidasi akan menimbulkan endapan pada jaringan perpipaan (Rahmawati, 2009).

Pada keadaan jenuh, laju adsorbsi menjadi berkurang sehingga waktu kontak tidak lagi berpengaruh (Sulistyawati, 2008). Sehingga waktu optimumnya selama 90 menit waktu kontak dan dengan kecepatan sebesar $100 \mathrm{rpm}$. Menurut Syauqiah, isna dkk (2011) Penggunaan kecepatan aduk di atas 90 rpm akan membuat ikatan antar partikel adsorben dan adsorbat terlepas. Di samping itu terlalu cepatnya pengadukan membuat arang aktif tidak sempat membentuk ikatan yang kuat dengan partikel logam.

\section{Penurunan Kadar Mangan (Mn) Sebelum dan Sesudah Penambahan Adsorben Karbon Aktif Jerami}

Tabel 2

PENURUNAN KADAR MANGAN (Mn) SEBELUM DAN SESUDAH PENAMBAHAN ADSORBEN KARBON AKTIF JERAMI

\begin{tabular}{ccccc}
\hline \multirow{2}{*}{$\begin{array}{c}\text { Kadar } \\
(\mathrm{gr} / \mathrm{L})\end{array}$} & \multicolumn{2}{c}{$\begin{array}{c}\text { Rata-Rata Kadar Mn } \\
\text { air sumur gali }(\mathrm{mg} / \mathrm{L})\end{array}$} & $\begin{array}{r}\text { Rata-Rata } \\
\text { Penurunan }\end{array}$ & $\begin{array}{c}\text { Persentase } \\
\text { Penurunan }\end{array}$ \\
\cline { 2 - 4 }$(\mathrm{mg} / \mathrm{L})$ & $\begin{array}{c}\text { Sebelum } \\
(\%)\end{array}$ \\
\hline 0 & 1.119 & 1.161 & -0.042 & 3.75 \\
5 & 1.119 & 1.127 & -0.008 & 0.71 \\
1 & 1.119 & 1.132 & -0.013 & 11.62 \\
15 & 1.119 & 0.984 & 0.135 & 12.06 \\
20 & 1.119 & 0.984 & 0.135 & 12.06 \\
25 & 1.119 & 0.977 & 0.142 & 12.68 \\
30 & 1.119 & 0.855 & 0.264 & 23.59 \\
\hline
\end{tabular}

Hasil persen penurunan diperoleh dari rumus perhitungan disamping :

$\% E=\left(\frac{c_{a w a l}-c_{a k h i r}}{c_{\text {awal }}}\right) \times 100 \%$

Keterangan :

$C_{\text {awal }}=$ Konsentrasi mangan awal $(\mathrm{mg} / \mathrm{l})$

$\mathrm{C}_{\text {akhir }}=$ Konsentrasi mangan akhir $(\mathrm{mg} / \mathrm{l})$

$\% E=$ Efisiensi adsorpsi

Berdasarkan hasil yang diperoleh dari Tabel 2 dapat diketahui bahwa ratarata penurunan kadar $\mathrm{Mn}$ tertinggi terjadi pada kode sampel $G$ dengan perlakuan penambahan massa karbon aktif jerami $30 \mathrm{gr}$ yaitu sebesar $0.264 \mathrm{mg} / \mathrm{L}$ (23.59\%). Data menunjukkan penurunan tertinggi rata-rata kadar mangan $(\mathrm{Mn})$ pada kode sampel $G$ dengan penambahan $30 \mathrm{gr}$ adsorben karbon aktif jerami sebesar $0.264 \mathrm{mg} / \mathrm{L}(23.59 \%)$ dengan sisa $0.855 \mathrm{mg} / \mathrm{L}$. Dibandingkan dengan besar penurunan yang terjadi pada kode sampai $A, B, C, D, E$, dan $F$ 
dengan penambahan massa karbon aktif jerami 5 gr, $10 \mathrm{gr}, 15 \mathrm{gr}, 20 \mathrm{gr}, 25 \mathrm{gr}, 30$ gr secara berurutan sebesar $-0,042 \mathrm{mg} / \mathrm{L}$ $(3.75 \%)$ dengan sisa rata-rata mangan $1.161 \mathrm{mg} / \mathrm{L}, \quad-0.008 \mathrm{mg} / \mathrm{L} \quad(0.71 \%)$ dengan sisa rata-rata mangan $1.127 \mathrm{mg} / \mathrm{L},-0.013 \mathrm{mg} / \mathrm{L}(1.11 \%)$ dengan sisa rata-rata mangan $1.132 \mathrm{mg} / \mathrm{L}, 0.135$ $\mathrm{mg} / \mathrm{L}(12,06 \%)$ dengan sisa rata-rata mangan $0.984 \mathrm{mg} / \mathrm{L}, \quad 0.135 \mathrm{mg} / \mathrm{L}$ $(12.06 \%)$ dengan sisa rata-rata mangan $0.984 \mathrm{mg} / \mathrm{L}$, dan $0.142 \mathrm{mg} / \mathrm{L}(12.68 \%)$ dengan sisa rata-rata mangan 0.977 $\mathrm{mg} / \mathrm{L}$.

Penurunan tertinggi kadar mangan Mn pada perlakuan penambahan adsorben karbon aktif jerami sebanyak $30 \mathrm{gr}$ dengan rerata penurunan sebesar $0.263 \mathrm{mg} / \mathrm{L}$, sedangkan penurunan terendah terjadi pada perlakuan penambahan adsorben karbon aktif sebanyak $5 \mathrm{gr}$ dengan rerata penurunan sebesar $0.042 \mathrm{mg} / \mathrm{L}$. Hal ini sama dengan penelitian Asy'ari, Muhammad Ikhsan, dan Sudibandriyo, mahmud (2014) menunjukkan bahwa semakin tinggi suhu aktivasi semakin tinggi pula persentaseburn off. Burn off adalah persentase pengarangan massa bahan baku jerami padi selama proses aktivasi dan pencucian hingga didapat produk karbon aktif. Hal ini menunjukkan semakin tinggi suhu aktivasi maka semakin banyak pula pori-pori yang terbentuk pada permukaan pada karbon aktif yang disebabkan oleh penguapan zat volatile dan meningkatnya intensitas pengikisan permukaan karbon aktif dari reaksi yang melibatkan activiting agent. Maka ini menjelaskan bahwa penurunan ion logam tergantung dari tinggi rendahnya massa suatu adsorben. Besarnya kapasitas adsorpsi suatu adsorben disebabkan luasnya permukaan karbon aktif ang berhubungan dengan ion logam Mn.

Oksidasi permukaan dalam produksi karbon aktif, akan menghasilkan gugus hidroksil, karbonil, dan karboksilat yang memberikan sifat amfoter pada karbon, sehingga karbon aktif dapar bersifat sebagai asam maupun basa (Nunik, P. 2015). Faktor internal yang berpengaruh yaitu $\mathrm{pH}$ air, suhu air, waktu kontak, dan kecepatan pengadukan, sedangkan faktor eksternal yang berpengaruh yaitu kelembaban udara, suhu udara. Faktor $\mathrm{pH}$ dan suhu air berpengaruh terhadap reaksi oksidasi yang terjadi pada proses pengadukan. Kadar mangan berpengaruh terhadap kelarutan gas oksigen di dalam air dan kelembaban udara akan mempengaruhi tekanan udara yang berdampak pula pada reaksi oksidasi (Joko, Tri Savitri. 2016). Hal tersebut mengakibatkan kenaikan massa jerami sebesar $0 \mathrm{gr}, 5 \mathrm{gr}, 10 \mathrm{gr}$ dan terjadi pada nilai $\mathrm{pH}$ yang tinggi dari percobaan yang lain.

Tabel 2

HASIL UJI NORMALITAS DATA KADAR Mn PADA AIR SUMUR GALI SESUDAH PENGOLAHAN DENGAN METODE JARTEST

\begin{tabular}{cccc}
\hline \multirow{2}{*}{$\begin{array}{c}\text { Kadar } \\
\mathbf{g r} / \mathbf{L}\end{array}$} & Statistik & Shapiro-Wilk \\
\hline 0 & 0.791 & 4 & Sig. (p-value) \\
\hline 5 & 0.914 & 4 & 0.087 \\
\hline 10 & 0.999 & 4 & 0,506 \\
\hline 15 & 0.976 & 4 & 0.998 \\
\hline 20 & 0.976 & 4 & 0,879 \\
\hline 25 & 0.778 & 4 & 0,878 \\
\hline 30 & 0.996 & 4 & 0.068 \\
\hline
\end{tabular}

Berdasarkan Tabel 3 dapat diketahui bahwa nilai Sig. ( $\rho$-value) atau nilai peluang kebenaran suatu hipotesis pada semua data bernilai $>0,05$ maka $\mathrm{H}_{0}$ diterima, yang berarti tidak ada perbedaan distribusi sampel dengan distribusi normal. Dikarenakan semua data berdistribusi normal, maka 
pengujian dilanjutkan dengan Uji Anova Satu Arah yang bertujuan untuk mengetahui perbedaan penurunan kadar Mn pada air sumur gali dari 7 perlakuan yang diberikan.

Berdasarkan hasil output uji homogenitas varians dengan menggunakan uji Levene, nilai signifikansinya adalah 0.229 . Karena nilai signifikansinya lebih dari 0.05 , maka dapat disimpulkan bahwa kelompok kontrol dan kelompok perlakuan yang mempunyai varians yang sama, atau kedua kelas tersebut homogen. Terdapat perbedaan rata-rata kadar $\mathrm{Mn}$ air sumur gali sebagai kontrol dengan kadar $\mathrm{Mn}$ sesudah pengolahan dengan metode jartest. Perbedaan rata-rata setiap perlakuan terhadap kadar $\mathrm{Mn}$ maka harus dilakukan uji lanjutkan (Post Hoc Test). Hasil analisis statistik menggunakan metode one way anova diketahui bahwa nilai $\mathrm{p}$ significance sebesar 0,00 yang artinya $p<0.05$ (a) maka terdapat pengaruh yang signifikan sehingga terjadi penurunan kadar mangan (Mn) pada air sumur gali setelah dilakukan penambahan adsorben karbon aktif jerami dengan variasi massa sebesar 5 gr, 10 gr, 15 gr, 20 gr, 25 gr, 30 gr. Berdasarkan uji lanjutan (Post Hoc Test) menggunakan uji LSD (Least Significance Different) diperoleh hasil perbedaan rata-rata signifikan terjadi pada perlakuan massa $30 \mathrm{gr}$. Hasil yang diperoleh dalam penelitian ini menunjukkan bahwa penurunan kadar Mn terbesar terjadi pada kode sampel G dengan penambahan $30 \mathrm{gr}$ adsorben yaitu sebesar $0.264 \mathrm{mg} / \mathrm{L} \quad(23.59 \%)$ dengan rata-rata kadar mangan $(\mathrm{Mn})$ sesudah perlakuan sebesar $0,855 \mathrm{mg} / \mathrm{L}$, sedangkan penurunan terkecil terjadi pada kode sampel B dengan penambahan 5 gr yaitu sebesar -0.042 $\mathrm{mg} / \mathrm{L}(-3.75 \%)$ dengan rata-rata kadar mangan $(\mathrm{Mn})$ sisa sebesar $1.161 \mathrm{mg} / \mathrm{L}$. Penambahan variasi dosis adsorben dalam bentuk karbon aktif jerami memberikan pengaruh yang besar dalam penurunan kadar mangan dalam air sumur gali semakin banyak massa adsorben yang digunakan dalam proses adsorpsi maka semakin tinggi terjadi penurunan kadar logam berat Mn. Hal ini sesuai dengan penelitian Asy'ari, dkk (2014) menunjukkan bahwa semakin tinggi suhu aktivasi semakin tinggi pula persentaseburn off. Burn off adalah persentase pengarangan massa bahan baku jerami padi selama proses aktivasi dan pencucian hingga didapat produk karbon aktif. Hal ini menunjukkan semakin tinggi suhu aktivasi maka semakin banyak pula pori-pori yang terbentuk pada permukaan pada karbon aktif yang disebabkan oleh penguapan zat volatile dan meningkatnya intensitas pengikisan permukaan karbon aktif dari reaksi yang melibatkan activiting agent. Maka ini menjelaskan bahwa penurunan ion logam tergantung dari tinggi rendahnya massa suatu adsorben. Banyaknya luas permukaan karbon aktif selain berhubungan dengan banyaknya jumlah adsorben juga dipengaruhi oleh ukuran partikel karbon aktif.

Selain massa adsorben dalam air, waktu kontak memberikan pengaruh yang besar dalam proses adsorpsi. Hal ini berkaitan dalam menghasilkan kapasitas adsorpsi maksimum yang terjadi pada waktu kesetimbangan. Proses adsorpsi dalam penelitian ini dilakukan pada waktu kontak 90 menit dengan kecepatan pengadukan sebesar $100 \mathrm{rpm}$, dan diendapkan selama 30 menit. Hal ini telah dibuktikan oleh Asbahani (2013) di dalam penelitiannya bahwa waktu kontak yang optimum dalam proses adsorpsi logam berat besi adalah 90 menit. Hal ini disebabkan pada waktu kontak 90 menit gugus aktif dari selulosa dalam mengikat ion logam timbal mencapai kondisi yang optimum. Dalam waktu kontak lebih dari 90 menit, gugus aktif dari selulosa mencapai keadaan konstan sehingga proses adsorpsi mengalami penurunan. Isna Syauqiah, dkk (2011) dalam kecepatan pengadukan diatas $90 \mathrm{rpm}$, proses adsorpsi terjadi penurunan karena pengadukan yang terlalu cepat membuat ikatan antar partikel adsorben dan adsorbat terlepas.

$\mathrm{pH}$ mempunyai pengaruh penting dalam proses adsorpsi. Kondisi optimum dalam proses adsorpsi terjadi pada kondisi pH 7-9. Pada saat proses 
adsorpsi antara adsorben jerami dengan adsorbat. Menurut Kusnaedi (2010) air yang mengandung $\mathrm{pH}<7$ bersifat asam. Jika hasil $\mathrm{pH}$ dibandingkan dengan Permenkes No. 32 tahun 2017 tentang standar baku mutu untuk air yang digunakan untuk keperluan higiene sanitasi, pH yang diperbolehkan 6,5-8,5 maka $\mathrm{pH} 7,86$ masih dalam standar yang diperbolehkan. Tumin, dkk (2008) menjelaskan bahwa pada $\mathrm{pH}$ terlalu asam yaitu 2-3 proses adsorpsi karbon aktif terhadap ion logam sangat kecil, hal ini dikarenakan terjadi persaingan antara ion $\mathrm{H}^{+}$pada permukaan karbon aktif dengan ion logam yang bersifat kation untuk berinteraksi dengan gugus fungsi karbon aktif.

\section{KESIMPULAN}

Rerata kadar mangan (Mn) sebelum perlakuan penambahan adsorben karbon aktif jerami lebih tinggi dibandingkan dengan rata-rata kadar $\mathrm{Mn}$ sesudah perlakuan. Jerami dapat dijadikan karbon aktif yang mampu menurunkan kadar mangan (Mn).

\section{SARAN}

Jerami dapat dimanfaatkan sebagai bahan alternatif adsorben karbon aktif untuk menurunkan kadar mangan (Mn) pada air sumur gali yang mengandung $\mathrm{Mn}$.

\section{DAFTAR PUSTAKA}

Abdi, Chairul., Khair, Riza Miftahul., dan Saputra, Wahyuddin.2015.Pemanfaatan Limbah Kulit Pisang Kepok (Musa acuminate L.) sebagai Karbon Aktif untuk Pengolahan Air Sumur Kota Banjarmasin : Fe dan Mn.Kalimantan Selatan.Jukung Jurnal Teknik Lingkungan, 1 (1): 8-15.

Aisyah, S.2010. Penurunan Angka Peroksida dan Asam Lemak Bebas (FFA) pada Proses Bleaching Minyak Goreng Bekas oleh Karbon Aktif Polong Buah Kelor (Moringa oleifera. Lamk) dengan aktivasi NaCl.Malang.

Asbahani. 2013."Pemanfaatan Limbah Ampas Tebu sebagai Karbon Aktif untuk Menurunkan Kadar Besi pada
Air Sumur".Jurnal Teknik Sipil

Untan.vol. 13.no. 1.2013 h:106

Asy'ari, Muhammad Ikhsan.;dan

Sudibandriyo,

Mahmud.2014.Pemanfaatan Jerami

Padi untuk Produksi Karbon Aktif dengan Aktivasi Kimia Menggunakan Kalium Karbonat.Depok. Teknik Kimia Universitas Indonesia.

Atmoko, R.D.2012.Pemanfaatan Karbon Aktif Batu Bara Terakomodasi $\mathrm{TiO}_{2}$ pada Proses Reduksi Gas Karbon Monoksida (CO) dan Penjernihan Asap Kebakaran.Skripsi. Program Sarjana Teknik Kimia, Fakultas Teknik I Universitas Indonesia. Jakarta.

Badan Pusat Statistik.2017.Jawa Timur dalam Angka.BPS. Jawa Timur.

Bouchard, Maryse F. Sebastien Sauve, Benoit Barbeau, Melissa Legrand, Marie-Eva Brodeur, Therese Bouffard, Elyse Limoges, David C. Bellinger and Donna Mergler (2010). "Intellectual Impairment in SchoolAge Children". Environmental Health Perspectives 119 (1):138-143

Fauziah, A.2010.Efektivitas Saringan Pasir Cepat dalam Menurunkan KadarMAngan $(\mathrm{Mn})$ pada Air Sumur dengan Penambahan Kalium Permanganat $\left(\mathrm{KMnO}_{4}\right) \quad$ 1\%.Skripsi FKM USU:Medan

Joko, T.2010. Unit Produksi dalam Sistem Penyediaan Minum.Yogyakarta.Graha Ilmu.

Lakherwal, D.2014.Adsorption of Heavy Metals:a

review.Int.J.Environ.Res.Dev. 4,4148.

Nunik P, \& Okayadnya. Penyisihan Logam Besi (Fe) Pada Air Sumur Dengan Karbon Aktif Dari Tempurung Kemiri. Jurnal Ilmiah Teknik Lingkungan 5 (2) HIm 33-41. 2015.

Peraturan Menteri Kesehatan Republik Indonesia Nomor 32 tahun 2017 Tentang Standar Baku Mutu Kesehatan Lingkungan dan Persyaratan Kesehatan Air untuk Keperluan Higiene Sanitasi, Kolam Renang, Solus Per Aqua dan Pemandian Umum. 
Purwono, Purnawati Heni.2009.Budidaya 8 jenis Tanamanan Pangan Unggul.Jakarta.Penebar Swadaya.

Rahmawati, S.; dan Sarbini, D.2009.Uji Praklinik:Efek fortifikasi Fe dan Zn pada Biskuit Tempe-Bekatul Terhadap Kadar Hemoglobin dan Albumin Mencit yang Kurang Gizi dan Anemia.Jurnal Penelitian Sains dan Teknologi 10(2):139-147.

Said, Nusa Idaman.2005. Metoda Penghilangan Zat Besi Dan Mangan Di Dalam Penyediaan Air Minum Domestik. Jurnal Air Indonesia. Vol. 1 No.3.

Sulistyawati, Sari.2008.Modifikasi Tongkol Jagung sebagai Adsorben Logam Berat $\mathrm{Pb}(\mathrm{II})$.Bogor. docplayer.info/5069366 7.

Syauqiyah, Isna, Mayang Amalia dan Hetty A. Kartini.2011.Analisis Variasi Waktu dan Kecepatan Pengadukan pada Proses Adsorpsi Limbah Logam Berat dengan Arang Aktif.Info Teknik.Vo 12, No 1.

Tumin, N., Luqman, Zawani, Suraya. 2008. Adsorption Of Copper From Aqueous Solution By Elais Guineensis Kernel Activated Carbon. Malaysia: University Kuala Lumpur. Journal of Engineering Science and Technology. Vol.3, No.2

Widowati., Sastiono., Jusuf.,2008.Efek Toksik Logam Pencegahan dan Penanggulangan

Pencemaran.Yogyakarta.Andi Offset. Zhaafirah, Hafshah., Fitriyano, Gema., dan Hasyim, Ummul Habibah.2017.Pengaruh Kecepatan Pengadukan terhadap Rendemen dan Identifikasi Selulosa Asetat Hasil Asetilasi dari Limbah Kulit Pisang Kepok.Jakarta.Universitas Muhammadiyah Jakarta.p-ISSN : 2407-1846, e-ISSN : 2460-8416. 